\title{
A Study on Democracy Metaphors in Moroccan King Mohammed VI Inaugural Speeches
}

ISSN: 2311-8636 (Print)

ISSN: 2312-2021 (Online)

Source of Support: Nil

No Conflict of Interest: Declared

Email for correspondence:

dr.charbati@yahoo.com However, in the Moroccan context, studies related to metaphors and politics have received little attention so far. Politicians encounter challenges as they address their audience such as the need to convince them of their views, to gain the trust of their analysis and to give psychological realities to their abstract concepts.

The Moroccan monarchy has ruled Morocco for centuries. More than three hundred and fifty years of monarchy rule has marked the history of Moroccan society. The monarchy was able to adapt to the sociopolitical changes that the Moroccan society has known. This rule was the work of multiple factors and strategies that the monarchy has followed. One of them is the use of metaphors as a communication strategy.

The aim of this paper is to reveal the contribution of metaphors to the Moroccan political debate mainly by studying the king's speeches addressed to the Moroccan nation. This research strives to uncover part of the Moroccan king's strategy to win the hearts and minds of the moroccan people. This study provides an insight into the communication strategies used by the head of state of one of the third world regimes facing democracy transition and encountering political and economic challenges. They are based mainly on the use of the metaphor to interpret realities and design future roadmaps.

Key Words: Moroccan king speeches, metaphor, democracy politics

\section{INTRODUCTION}

Much research on the political system of Morocco has been carried out from different approaches. But there is a lack of research regarding the use of figurative language and how it affects the Moroccan reality. Many language philosophers and linguists have discussed the role of the metaphor in politics (George Lakoff 2002). The metaphor is a powerful tool used in convincing the hearer because it embeds assumptions and logical connections used as a basis for conceptualizing an issue. Studies carried out on metaphor since the 1980s had impacted significantly linguistic political sciences and linguistics. 
However in the Moroccan context, the role of the metaphor has yet to be given its due attention because cognitive linguistics has not been established in Morocco as a science yet.

Since the independence of Morocco, the political opposition mainly the Socialist Union of Popular Forces aimed at limiting the late King Hassan II's authorities. The late king had great powers, and his assistants were considered to have great authorities. When the King Mohammed IV took over, He declared his determination to make Morocco a democratic country. He expressed his views toward democracy and how he decided to achieve it by the use of metaphors.

The monarchy has to meet the needs of the Moroccans. One of these needs is their need of democracy. The monarchy has to convince Moroccan people that it can provide democracy to them. The king Mohammed VI has declared that he had chosen the path of democracy. He stressed that democracy means a process and not just a wish. When the king declared the process of democracy, he made it clear that it would happen one day and that it needed time. Convincing Moroccans of such view, metaphors were to be used.

This study focuses on the metaphors used in Mohamed IVs' speeches to convey his views towards issues of special significance to the Moroccan people mainly democracy. These speeches aim at convincing people that the king is determined to achieve democratization of the country. The metaphors are important because they express views and construct realities. They make people view things through them as they provide concepts that summarize their realities. They also provide frames based on which people are supposed to understand their economical, social and political situations.

This article discusses the role of the metaphor within the paradigm established by Lakoff and Johnson (1980). The development of the new conception of the metaphor was the work of many linguists and language philosophers, but the work of lakoff and Johnson (1980) provides a detailed explanation of the mechanisms used in the understanding of our reality based on metaphor.

The aim of this paper is to look into the governing of the Moroccan people by the monarchy through the metaphors embedded in the king's speeches. These metaphors create convictions necessary for preserving loyalty to the regime. Metaphors form beliefs by the entailments they embed. The Moroccan King Mohammed IV has used metaphor as a tool to win the hearts and minds of Moroccans and to convey its version regarding many important political concepts.

\section{LITERATURE REVIEW}

Our mind works by understanding one thing in terms of another and thus providing truth. This truth is not absolute but culturally dependent. The metaphor is used as a tool to create realities and form beliefs. The reality is a metaphorical construction and does not reflect objective facts. Relations between the different components of this reality are "blended" into an image that the regime tries to convey. Usually, metaphors convey this blending of different components of reality by a process known as Conceptual Blending. Gilles Fauconnier and Mark Turner (2003) have advocated this process and uncovered the relation of conceptual blending to formal linguistic expression.

Ottati and Renstorm (2010) stress that there is a psychological process mechanism responsible for the effects of metaphor in framing public opinions. He emphasized that 
political communication works by activating what he called a root metaphor. This root metaphor maps the message target (e.g. "Operation Desert Storm") to the metaphor source and influences the impressions of the recipient.

Michael Hanne, William D. Crano, Jeffery Scott Mio (2014) carries out a thorough research on the cognitive and rhetorical functions of metaphor. Their aim is to document current thinking on the many ways in which narrative and metaphor functions as a cognitive instrument in political discourse both domestic and international. They focus on the role of metaphors in conceptualizing and communicating political issues, for example, Bashar al Assad equated his role as a Syrian leader with the role of the surgeon who has to cut, clean and amputate. He used this metaphor to justify his war on the Syrian revolution.

Terrell Carver and Jernej Pikalo (2011) try to combine theoretical concepts about metaphor with empirical research to advance understanding on political issues such as election and international relations. They clarify the role of metaphor in uncovering our perception of politics. They advocate new methodological approaches to uncover the use of metaphor in political science and international relations by mainly combining theory with case studies. Their focus is to show the influence of metaphor in our perception in electoral and policy related politics.

Karrin Vasby Anderson and Kristiana Horn Sheller (2005) focus on uncovering stereotypes framing women in US politics. They stress that women are portrayed as mothers and caregivers while as rational thinkers and that these stereotypes obstruct women seeking public office. They emphasize the importance of metaphors in the construction of political reality, but with a particular focus on the role of gender in the American politics. They reveal sexual constraints that have trapped political women and were mainly the product of metaphor in shaping and constructing women's realities in the realm of politics.

Andreas Musolff (2004) analyzes the use of metaphors in public discourse showing differences in the UK and German attitudes in argumentation. Musolff highlights the historical value of metaphor as well its ethical dimension. He focuses on the role of metaphor in shaping political argumentation. Drawing on a bilingual corpus, he shows German and British argumentation differences based on metaphor. He also explains the ethical dimension of metaphor in politics.

Perry Link (2003) provides a comprehensive study of the use of language primarily metaphorical language in China politics. He confirms that the impact of metaphor on the rhetoric of slogans is part of linguistic tools that explain the effects of slogans in communists' politics.

\section{Methodology}

The methodology adopted in this research examines the use metaphors in about democracy in the Moroccan kings speeches addressed to the Moroccan nation. The king delivered them during parliament opening sessions from 2003 until 2014. They are available online at http://www.parlement.ma. They represent the king views towards many political issues.

This research has selected speeches addressed by the king directly to the Moroccans and, therefore, the king is fully responsible for their contents. The researcher has not included in this study letters read by the king's assistants because it can be argued that these letters may not be written in consultation with him. The researcher has selected speeches directed 
to the Moroccan nation instead of those directed to the outsiders as outsiders may receive different content from the locals.

The Metaphors used are noted, and assumptions embedded in them revealed. The researcher will gather all the metaphors used to see if these metaphors if put together constitute a systematic approach towards democracy or used according to the various meanings the king conveys and not in liaison with each other.

\section{DatA ANALYSIS}

At the opening of the parliamentary session 2003-2004, the King Mohammed VI mentions the following metaphor: Democracy is a path.

$$
\text { الحرفن الثانسي، العدبق ووفاؤنا الصادق، للروح الطاهرة لرائد المسبرة الدبيقراطبة، والدنا المنعم، جلالة الملك }
$$

Our deep gratitude and sincere loyalty to the pure spirit of the leader of the democratic process, our revered father His Majesty King Hassan II, May God blesses his soul.

He also uses in the same speech the metaphor 'democracy is a difficult and long way'.

$$
\text { لقد أكدنا مرارا ، ألا دبيقر اطية بلون ديبقر اطبين، وأن الدبيقر اطبة طريق شاق طويل. }
$$

We have emphasized repeatedly, no democracy without democrats, and that democracy is a difficult and long way.

The king considers democracy as a path that leads to development. He stresses that democracy is not having election and taking seats in parliament and therefore the representatives are fully responsible of their duties. To convey this meaning 'Democracy of seats' metaphor is used. By 'democracy of seats', he means winning the election and becoming parliament members.

$$
\text { فإن احترام الإرادة الشعبية بقضضي نبذ عقلبة دبيقر اطبة المقاعد }
$$

Respecting the will of the people requires rejecting democracy of seats mentality,

When the king addressed the parliament in 2004-2005 legislative years, he uses another metaphor and that is 'democratic transition'. This metaphor views democracy as a movement shifting from one stage to another. He says:

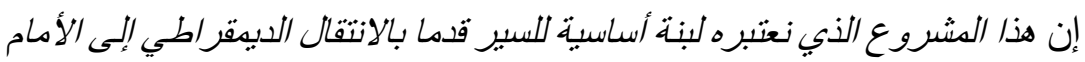

This project, which we consider an essential building block to move forward the Democratic move forward

On the legislative year 2005-2006, the king Mohammed VI addressed the parliament and laid out the history of democracy in Morocco. He confirmed that its achievement in Morocco dated back to his grandfather who had put its foundations. The king used the metaphor 'democracy has foundations'. This metaphor gives the impression that putting democracy in place is a process started by his grandfather, deepened by his father and currently by him. His father's legacy and his contribution to the implementation of democratic measures are part of the things that provides legitimacy to the throne. 


\section{فقد كان، أكرم الله مثو/ه، رائد/ في إرساء دعائح الدبيقر اطبة ، من خلال إنجاز ات تاريخية، وفي طليعتها

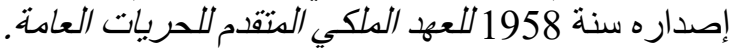

Revered grandfather, His Majesty King Mohammed V. He was, may he rest in peace, a pioneer in establishing the foundations of democracy, through the historical achievements, at the top of issuance, in 1958, advanced to the royal era of public freedom.

'Democracy is an edifice' and 'democracy is a path' are two metaphors mentioned in the king's speech delivered in 2009-2007 in the parliament. He says:

$$
\text { توطيد صرحنا الديمقر اطي }
$$

Consolidating democratic we have stated,

He also says:

$$
\text { تعزيز المسار الديمقر اطي }
$$

Strengthening the path of democracy

At the opening of the parliamentary session 2007-2008, the king stresses the importance of elected councils and their relations to democracy. He uses the metaphor 'local councils are the lever of democracy'. The aim of this metaphor is to highlight the importance of the local councils by considering them as part of democracy. He says:

$$
\text { غايتنا تعزيز مصالحة المواطن مع المجالس المنتخبة، بجعلها رافعة قوية للتنمية و الديمقر اطية }
$$

Our goal is to promote citizens reconciliation with elected councils by making it a powerful lever of development and democracy.

The King implies that democracy exists in the country, and this is manifested in the existence of democratic councils with elected representatives. In the next speech delivered in 2008-2009 in the parliament, we can see the relation between democracy and the election of local representatives. The metaphor 'Local councils are the base of democracy' is used. He says:

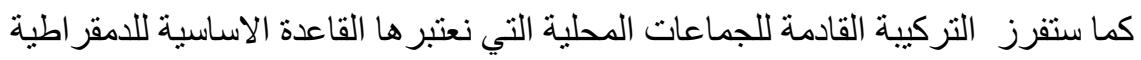

Also, it will produce the next combination of the local councils, which we consider the main base for democracy.

Since local councils are part of a democratic process, it follows that any election is a stage in the building of democracy, the metaphor 'Democracy is a construction' conveys this meaning. At the opening of the parliamentary session 2009-2010, the King used this metaphor.

$$
\text { فهوه الاستحقاقات لببست الا شوطا في بناء دبيقر اطي }
$$

These elections are only one part of a democratic construction

After stressing the relation between democracy and the existence of local councils, the King emphasizes the connection between democracy and the existence of an active parliament through the metaphor: 'Parliament is a lever of democracy' mentioned in the king's speech delivered at the opening of the parliamentary session 2010-2011. 


$$
\begin{aligned}
& \text { بيب أن هذه المكانة النبابية المتمبيزة ، تسائل الجمبع: إلى أي مدى بنهض البرلمان بلوره كاملا ، كرافعة }
\end{aligned}
$$

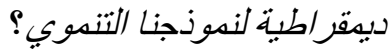

However, this distinctive parliamentary position questions everyone: the extent to which the Parliament plays its part fully as a Democratic lever for our development model.

On the occasion of the opening of the legislative year 2011-2012, the king delivered a speech that states two metaphors, 'democracy is a path' and 'political parties are part of Democracy'. He says:

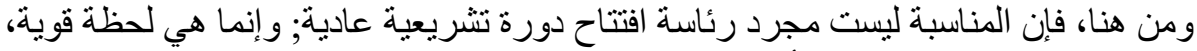

$$
\begin{aligned}
& \text { لاستشر اف الولاية البرلمانية الأولى، في العهد الدستوري الجديد، وتدشين مرحلة تاريخية، في مسار }
\end{aligned}
$$

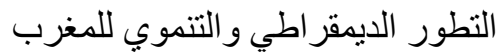

Hence, the occasion is not just the presidency of the opening of the regular legislative session, but a powerful moment to explore the first parliamentary mandate in the new constitutional era, and the launch of a historical stage in the Moroccan democratic and developmental path.

$$
\text { كما تشدل هذه التحديات التأهبل الذاتي للأحزاب، التي لا ديدقراطبة حقة بدونها }
$$

These challenges also include self- rehabilitation of the (political) parties, without which there is not a true democracy.

The metaphor 'Democracy is a path' serves to convey the message that Morocco is making progress in achieving democracy. The metaphor 'Democracy is political parties' aims to show the participatory approach that the king has with regards to the political parties.

In the next speech delivered at the opening of the parliamentary session 2012-2013, the king uses another metaphor to confirm the fact that the regime has been moving towards the path in the establishment of democracy. He uses the metaphor: 'democracy progresses'.

$$
\text { حضرات السبدات و السادة, ل بخفى علبكم ما بقتضبه هذا التقدم الدبيقراطي الوازن من متطلبات جديبة }
$$

Ladies and Gentlemen, it is not beyond your knowledge that this democratic progress has new requirements.

In the following speech delivered at the opening of parliamentary session 2013-2014, there is a reference to the democratic principles and their manifestation in the pluralistic parliamentary tradition in the country. Therefore, the metaphor: 'democracy gives birth to pluralistic parliamentary'. He says:

$$
\begin{aligned}
& \text { دلك ان المدارسة البرلمانبة التعددية بيلادنا لبيت ولبية الأمس، بل هي خبار استراتبجي بيتد على مدى التى }
\end{aligned}
$$

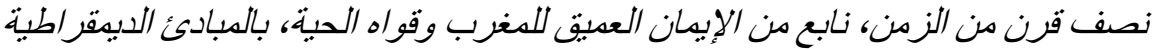

As you know, the pluralistic parliamentary practice in our country does not date back to yesterday. It is a strategic option, which spans over half a century. It stems from the strong, deep- rooted commitment of Morocco and of all the forces that make the life blood of the nation, to the principle of democracy. (http:/ / www.maroc.ma/en/royal-speeches/full-text-hm-kings-speech-openingfirst-session-third-legislative-year-ninth) 
The success of the Moroccan model depends on the existence of participatory institutions such as local councils. The existence of such institutions proves that there is democracy in the country. Hence, arises the need to use the metaphor: 'Democracy has participatory institutions' in the king's speech delivered at the opening of the parliamentary session 20142015, he says:

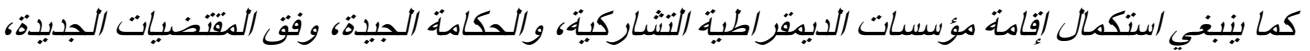

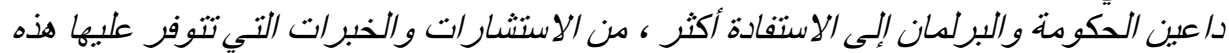

$$
\begin{aligned}
& \text { المؤسسات. }
\end{aligned}
$$

Similarly, the task of setting up the institutions of the participatory democracy and good governance should be completed in accordance with the new provisions. I invite the Government and Parliament to take more advantage of the expertise available in these institutions. (http://www.maroc.ma/en/royalspeeches/full-text-royal-speech-opening-fourth-legislative-year).

Institutions according to the previous metaphor are partners in fulfilling the task of good governance. In fact, these partners are being held responsible for any economic or social failure This means that any failure is the responsibility of the elected candidates, that is, Moroccans have to blame the elected officials for any unsatisfactory results because democracy needs to be kept up by political actors; thus giving birth to the metaphor: 'Democracy is to be kept up by political players'.

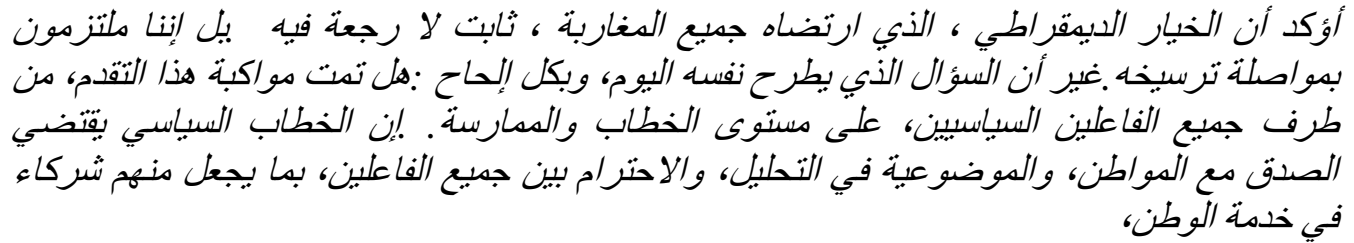

I should like to emphasize, in this respect, that the democratic choice made by the Moroccan people is irreversible. In fact, I am committed to seeing that this choice is further consolidated. The pressing, the inevitable question today is: Have all political players kept up with this progress in (their) words as well as in deeds?

Political discourse requires being honest with the citizens, making objective analyzes and ensuring that players show mutual respect, so they can all be partners in serving the nation.(http:/ / www.maroc.ma/en/royal-speeches/fulltext-royal-speech-opening-fourth-legislative-year)

The king claims that he is setting a progress and questions the integrity of the politicians and elected officials. His speech states two assumptions: the fact that the king is doing his best and the second is that the elected officials are not doing their parts.

\section{FINDINGS}

One of the major findings of this research is that there is a metaphorical system in which democracy is presented in different concrete concepts; all of them are based on two abstract metaphors: 'Democracy is a path' and 'democracy is a construction'.

The metaphor 'Democracy is a construction' represents a category that includes some metaphors manifesting building or building parts, thus giving birth to the metaphor 'Democracy is an edifice', 'democracy is not (parliament) seats', democracy has 
foundations', "Local councils are the base of democracy'. 'Political parties are part of democracy' and 'Democracy has participatory institutions.' Since any building can be a container of certain things, it follows that parliamentary practice stems from democratic principles, thus giving birth to the metaphor 'democracy gives birth to pluralistic parliamentary.'

Moreover, the relation between democracy and democratic institutions is expressed in terms of building tools; thus giving birth to the metaphor: 'Local councils are the lever of democracy' and 'Parliament is a lever of democracy'.

On the other hand, 'Democracy is a path' represents another category that includes 'democratic transition', 'Democracy progresses', 'democracy is a long and difficult way' and Democracy is to be kept up by political players'. All these metaphors are used to express different views and concepts based on the conceptual metaphor 'democracy is a path'.

More importantly, this study reveals that the Moroccan regime addresses the Moroccan people through the metaphor to convey certain messages mainly the need to be patient and the need to be optimistic. These messages if communicated directly could be interpreted in different ways by a wide audience. Using metaphors allows the king to convey these messages implicitly and smoothly.

The first message: inviting Moroccans to be patient. Two metaphors convey this message 'Democracy is a path' and 'democracy is a long and difficult way'. The second message is that Morocco is making progress as far as democracy is concerned and that the country is making gradual achievements starting from the late king who has put the foundations of democracy, thus giving birth to the metaphor 'democracy has foundations'.

The establishment of local councils is a major step in achieving democracy, thus giving rise to the metaphor 'democracy is local councils'. The role of democratic institutions in achieving democracy gives rise to the metaphors 'Parliament is a lever to democracy', 'Democracy is political parties' and 'Democracy is participatory institutions'. These metaphors imply that pillars of democracy are already in place and that the country is making democratic progress.

The third message is that any failure in achieving development is caused by elected officials and not the regime as we can see in the metaphor 'Democracy of seats' and the metaphor 'Democracy is to be kept up by political players'. These two metaphors imply that elected officials are to blame for any unsatisfactory results and that democracy needs to be kept up by political players. The metaphors express these messages implicitly.

\section{CONCLUSION}

This article is a new contribution in the area of political studies based on metaphors. It deals with strategies used in communicating certain messages to the Moroccan public opinion. The findings show that Mohammed VIs' speeches have used metaphors to convey important messages to the public mainly the fact that the state is working for their benefit and that insufficient democracy is normal due to the long process it needs to take place.

The king uses metaphors to convey his views on democracy and its role in development. These metaphors are necessary because they create logical connections between democracy and other players. These metaphors influence the way citizens' reason about democracy and its relation to Moroccan reality. Also, these metaphors embed assumptions that help 
Moroccans answer part of the complex issues they ask with regards to the interconnection between democracy and development, the long path of democracy and the reasons behind the difficulties facing the Moroccan democratic model in achieving development.

The path of democracy chosen by the King focuses on the behaviors of elected officials rather than the constitutional authorities given to them. The Moroccan people who are unable to see the fruits of democracy are still wondering about the reasons behind the lack of prosperity in Morocco. The officials according to these speeches are to blame for any unsatisfactory results.

The King informs Moroccans that he is determined to achieve democracy and development, that there is hope the future, that they have to be patient and wait for democracy to happen gradually. To convey this, the metaphor 'democracy is a path' and ' democracy is a building' are two conceptual metaphors based on which other metaphors are used to convey the theoretical framework proposed by the king to perceive the Moroccan reality and design the political and economic future.

The metaphors used by the king influence how Moroccans see their political reality. It is hard to find someone in morocco who does not believe that morocco is involved in a democratic process and taking steps on democratic path. Finally, it is interesting to note that Moroccans do not recognize metaphors as an influential component in their understanding of the kings' speeches. In fact, there has not been any reference to metaphors in any analysis of the kings' speeches so far, and no study has been done to show that the metaphors used in political speeches describing the Moroccan reality are only metaphors.

\section{REFERENCES}

Fauconnier, G.and M.Turner (2003), The Way We Think, Basic Books, New York.

Haser, V. (2005), Metaphor, metonymy, and experientialist philosophy: Challenging cognitive semantics, Mouton, Berlin.

Kristina Horn Sheeler and Karrin Vasby Anderson (2005), Governing Codes: Gender, Metaphor, and Political Identity (Lexington Studies in Political Communication), Lexington Books. Lanham, Maryland.

Lakoff, G. (2002), Moral Politics: How Liberals and Conservatives Think, University of Chicago Press. Chicago.

Lakoff, G., E Johnson, M. (1980), Metaphors we live by, The University of Chicago Press, Chicago.

Mark Turner (1987), Death is the Mother of Beauty: Mind, Metaphor, Criticism, University of Chicago Press, Chicago.

Michael Hanne, William D. Crano, Jeffery Scott Moi(2014), Warring with Words: Narrative and Metaphor in Politics, Psychology Press, New York.

Musolff, A. (2004), Metaphor and Political Discourse Analogical Reasoning in Debates about Europe, Palgrave Macmillan, London.

Ottati, V.C., \& Renstrom, R.A. (2010), “Metaphor and Persuasive Communication: A Multifunctional Approach." Social and Personality Psychology Compass4/9, 783-794.

Perry Link (2013), An Anatomy of Chinese - Rhythm, Metaphor, Politics, Harvard University Press, Cambridge, Mass.

Terrell Carver, Jernej Pikalo (2011), Political Language and Metaphor: Interpreting and changing the world, Routledge; Reprint edition, London. 
Publish Online and Print Version Both

Online ISSN: 2312-2021

Google Scholar: https://goo.gl/eozEWi 